Article

\title{
Semi-Quantitative, Duplexed qPCR Assay for the Detection of Leishmania spp. Using Bisulphite Conversion Technology
}

\author{
Ineka Gow ${ }^{1,2},{ }$, Douglas Millar ${ }^{2}{ }^{\circledR}$, John Ellis ${ }^{1} \mathbb{D}$, John Melki ${ }^{2}$ and Damien Stark ${ }^{3}$ \\ 1 School of Life Sciences, University of Technology, Sydney, NSW 2007, Australia; john.ellis@uts.edu.au \\ 2 Genetic Signatures Ltd., Sydney, NSW 2042, Australia; doug@geneticsignatures.com (D.M.); \\ john@geneticsignatures.com (J.M.) \\ 3 Microbiology Department, St. Vincent's Hospital, Sydney, NSW 2010, Australia; damien.stark@svha.org.au \\ * Correspondence: ineka.c.gow@student.uts.edu.au; +61-466263511
}

Received: 6 October 2019; Accepted: 28 October 2019; Published: 1 November 2019

\begin{abstract}
Leishmaniasis is caused by the flagellated protozoan Leishmania, and is a neglected tropical disease (NTD), as defined by the World Health Organisation (WHO). Bisulphite conversion technology converts all genomic material to a simplified form during the lysis step of the nucleic acid extraction process, and increases the efficiency of multiplex quantitative polymerase chain reaction (qPCR) reactions. Through utilization of qPCR real-time probes, in conjunction with bisulphite conversion, a new duplex assay targeting the 18S rDNA gene region was designed to detect all Leishmania species. The assay was validated against previously extracted DNA, from seven quantitated DNA and cell standards for pan-Leishmania analytical sensitivity data, and 67 cutaneous clinical samples for cutaneous clinical sensitivity data. Specificity was evaluated by testing 76 negative clinical samples and 43 bacterial, viral, protozoan and fungal species. The assay was also trialed in a side-by-side experiment against a conventional PCR (cPCR), based on the Internal transcribed spacer region 1 (ITS1 region). Ninety-seven percent of specimens from patients that previously tested positive for Leishmania were positive for Leishmania spp. with the bisulphite conversion assay, and a limit of detection (LOD) of 10 copies per PCR was achieved, while the LOD of the ITS1 methodology was 10 cells/1000 genomic copies per PCR. This method of rapid, accurate and simple detection of Leishmania can lead to improved diagnosis, treatment and public health outcomes.
\end{abstract}

Keywords: leishmaniasis; qPCR; bisulphite

\section{Introduction}

Leishmaniasis is an infection caused by some species of Leishmania parasites that affect the skin, organs and mucosal regions of the body, leading to serious morbidity and possibly death. It is classed as a Neglected Tropical Disease (NTD), affecting 12 million people worldwide, with a further 350 million people at risk of contracting the disease [1]. With the advent of increased human international travel, due to work, tourism or war, leishmaniasis is now an emerging infectious disease, with an increased impact on global mortality and morbidity [2]. It is becoming increasingly clear that there is a need for accurate and rapid detection of Leishmania in the form of a standardized and validated assay, to aid diagnosis, treatment and surveillance programs.

Many validated molecular Leishmania detection assays use conventional PCR (cPCR) for the detection of Leishmania infection [3-5]. Conventional PCR is a diagnostic method where DNA is amplified using a thermal cycler, amplicons are separated due to molecular weight by electrophoresis, and detected by stain (usually ethidium bromide or gel red) and UV light (via a transilluminator) [6]. 
This approach requires significantly more hands-on time, has a greater risk of contamination and makes multiplexing analysis more difficult if products are similar in size, compared to real-time PCR. Probe-based qPCR can overcome these issues. Additionally, specificity can be increased, and it allows for continuous monitoring of the PCR. The $18 \mathrm{~S}$ rRNA gene (18S rDNA) is a highly conserved gene across all Leishmania species, despite having diverged from other similarly related species during the period Paleogene or Paleocene [7]. The gene exists in between 50-200 copies per Leishmania genome, making it an excellent choice for a pan-Leishmania detection assay [6]. To assess whether this target can be used in a novel diagnostic assay, based on bisulphite conversion and real-time PCR technologies, a series of experiments were performed to assess the limit of detection and sensitivity of the assay, and the new assay was compared to a CPCR, based on the ITS1 region, developed by Schönian et al. [8].

The development of this novel bisulphite-converted, qPCR assay methodology, based on genus-specific primer and probe designs for the $18 \mathrm{~S}$ rDNA, and its validation, is described in this paper. Furthermore, the bisulphite conversion and purification of protozoan DNA are discussed. The assay's limit of detection was 10 cellular or genomic copies/PCR, with clinical sensitivity and specificity demonstrated to be $97.0 \%$ and $100 \%$, respectively. The assay takes under 2.5 hours to complete, making the assay a potential diagnostic tool for both diagnostic and research laboratories worldwide.

\section{Materials and Methods}

\subsection{Specimens Tested}

DNA was purified from cell-cultured promastigotes of the following species: L. donovani (MHOM/IN/80/DD8 supplied at $2.3 \times 10^{7}$ cells/mL), L. braziliensis (MHOM/BR/75/M2903 supplied at $1.63 \times 10^{8}$ cells $\left./ \mathrm{mL}\right)$, L. tropica $\left(\mathrm{MHOM} / \mathrm{SU} / 74 / \mathrm{K} 27\right.$ supplied at $1.03 \times 10^{7}$ cells $\left./ \mathrm{mL}\right)$, L. amazonensis (MHOM/BR/73/M2269 supplied at $\left.9.9 \times 10^{6} \mathrm{cells} / \mathrm{mL}\right)$, L. mexicana $(\mathrm{MHOM} / \mathrm{BZ} / 82 /$ BEL21 supplied at $1.51 \times 10^{8}$ cells $/ \mathrm{mL}$ ) and L. major $\left(\mathrm{MHOM} / \mathrm{SU} / 73 / 5-\mathrm{ASKH}\right.$ supplied at $7.1 \times 10^{6}$ cells $\left./ \mathrm{mL}\right)$, obtained from the American type culture collection (ATCC, Manassas, USA). Leishmania infantum genomic DNA (supplied at $1.2 \times 10^{7} \mathrm{copies} / \mathrm{mL}$ ) was obtained from Vircell (Vircell, Granada, Spain). The assay was initially evaluated by performing a 10-fold serial dilution series of the DNA from these strains to assess the limit of detection. In addition, DNA from 67 previously extracted cutaneous clinical samples (derived from 66 unique patients), that were previously identified by St. Vincent's Hospital, Sydney as positive for Leishmania by the cPCR method, during the period 2007-2016, were included in the study [8-10]. All DNA was initially extracted using the EZ1 tissue kit on the EZ1 biorobot (Qiagen, Hilden, Germany), in accordance with manufacturers' recommendations regarding direct sample or following culture. Specificity was assessed by extracting DNA using standard methods from 76 negative tissue samples, previously characterised at St. Vincent's Hospital, Sydney, and 43 potential cross-reacting organisms, and testing them in the assay (Table 1). The clinical specimens were tested in accordance with St Vincent's Hospital ethics approval, HREC number LNR/16/SVH/231.

Table 1. List of organisms used in this study for cross-reactivity testing for the novel bisulphite conversion assay.

\begin{tabular}{cc}
\hline Specimen Number & Organism \\
\hline 1 & Acinetobacter baumanni \\
\hline 2 & Bacillus cereus \\
\hline 3 & Bacillus subtilis \\
\hline 4 & Clostridium perfringens \\
\hline 5 & Clostridium sordelli \\
\hline 6 & Escherichia coli \\
\hline
\end{tabular}


Table 1. Cont.

\begin{tabular}{|c|c|}
\hline Specimen Number & Organism \\
\hline 7 & Haemophilus influenzae \\
\hline 8 & Klebsiella oxytoca \\
\hline 9 & Klebsiella pneumoniae \\
\hline 10 & Moraxella cattaharalis \\
\hline 11 & Proteus mirabilis \\
\hline 12 & Proteus vulgaris \\
\hline 13 & Pseudomonas aeruginosa \\
\hline 14 & Staphylococcus aureus \\
\hline 15 & Staphylococcus hominis \\
\hline 16 & Streptococcus pyogenes \\
\hline 17 & Streptococcus sp. (mutans) \\
\hline 18 & Yersinia sp. \\
\hline 19 & Mycobacteria abscessus \\
\hline 20 & Mycobacteria marinum \\
\hline 21 & Mycobacteria sp. \\
\hline 22 & Herpes Simplex Virus Type I \\
\hline 23 & Herpes Simplex Virus Type II \\
\hline 24 & Varicella Zoster Virus \\
\hline 25 & Trichophyton tonsurans \\
\hline 26 & Trichophyton mentagrophytes \\
\hline 27 & Microsporum canis \\
\hline 28 & Aspergillus fumigatus \\
\hline 29 & Acromium pulluans \\
\hline 30 & Acromium strictum \\
\hline 31 & Aspergillus sp. \\
\hline 32 & Bipolaris sp. \\
\hline 33 & Fusarium $s p$. \\
\hline 34 & Penicillium sp. \\
\hline 35 & Scedosporium prolificans \\
\hline 36 & Trichophyton rubrum \\
\hline 37 & Bovine \\
\hline 38 & Human \\
\hline 39 & Trypanosoma cruzi \\
\hline 40 & Crithidia lucilae \\
\hline 41 & Trichomonas vaginalis \\
\hline 42 & Giardia intestinalis \\
\hline 43 & Entamoeba histolytica \\
\hline
\end{tabular}




\subsection{DNA Conversion and Quality Control}

Genomic DNA was bisulphite converted by adding $2,880,000$ or 28,800 copies of DNA/cellular standards, depending on available starting concentration, to a total volume of $150 \mu \mathrm{L}$ with molecular grade $\mathrm{H}_{2} \mathrm{O}$, then adding $250 \mu \mathrm{L} 3 \mathrm{M}$ sodium bisulphite. Alternatively, $5 \mu \mathrm{L}$ of DNA, previously extracted from cutaneous clinical sample DNA, were added to $145 \mu \mathrm{L}$ of molecular grade $\mathrm{H}_{2} \mathrm{O}$, then $250 \mu \mathrm{L} 3 \mathrm{M}$ sodium bisulphite was added. One negative process control of $150 \mu \mathrm{L}$ molecular grade $\mathrm{H}_{2} \mathrm{O}$ was included in each run, to check for contamination. A total of $5 \times 10^{5} \mathrm{copies} / \mu \mathrm{L}$ Lambda DNA (strain cI857 ind 1 Sam 7) (New England Biolabs, Ipswich, USA), an Escherichia coli bacteriophage, was added to each of these reactions, then the samples were mixed by vortexing, and incubated at $95^{\circ} \mathrm{C}$ for 15 minutes. Subsequently $200 \mu \mathrm{L}$ of this lysate was purified on the GS-mini (Genetic Signatures Ltd., Sydney, Australia) with the Sample Processing Pathogens A kit (Genetic Signatures Ltd., Sydney, Australia), according to the manufacturers' recommendations. The eluted DNA was then diluted in molecular grade $\mathrm{H}_{2} \mathrm{O}$ in 10-fold dilution series, to 0.1 copy per PCR. The limit of detection (LOD) for this study was defined as the lowest concentration of DNA at which the assay detected 10 out of 10 replicates, in accordance with CLSI standards, which define the LOD as the lowest dilution where $95 \%$ of replicates are positive [11]. Cell and DNA concentrations were provided by the suppliers and copy number was calculated (https://www.thermofisher.com/au/en/home/brands/ thermo-scientific/molecular-biology/molecular-biology-learning-center/molecular-biology-resourcelibrary/thermo-scientific-web-tools/dna-copy-number-calculator.html). The GS-mini employs a closed cartridge-based system, whereby nucleic acid is bound to magnetic beads, with subsequent washing and, finally, elution steps, using heating and shaking to increase nucleic acid yield. Separate PCR areas were used for mastermix preparation, DNA seeding and PCR reactions, to prevent the possibility of PCR contamination. The addition of lambda bacteriophage DNA to the PCR reaction was used to monitor the efficiency of the bisulphite conversion, purification, and in assessing for possible false negatives due to PCR inhibition. A negative process control (molecular grade $\mathrm{H}_{2} \mathrm{O}$ ) controlled for possible PCR contamination.

An external positive control was developed by creating a geneblock-a synthetic double stranded 1000bp-long fragment of the $18 \mathrm{~S}$ rDNA of L. donovani, (GenBank accession CP022642 positions 1047751 to 1048750), consisting of adenine, thymine, cytosine or guanine residues only. This was bisulphite converted and diluted to five copies/ $\mu \mathrm{L}$ in molecular grade $\mathrm{H}_{2} \mathrm{O}$, using the previously described protocol.

\subsection{PCR Primer and Probe Design}

For the $18 \mathrm{~S}$ rDNA assay forward, reverse primers and a probe were designed, based on multiple sequence alignments of the $18 \mathrm{~S} \mathrm{rDNA}$ in bisulphite converted form (that is, with all cytosines converted to thymines), of the species Leishmania aethiopica, Leishmania amazonensis, Leishmania braziliensis, Leishmania colombiensis, Leishmania donovani, Leishmania guyanensis, Leishmania infantum, Leishmania lainsoni, Leishmania major, Leishmania mexicana, Leishmania naiffi, Leishmania panamensis, Leishmania shawi and Leishmania tropica. This resulted in the identification of primers PL-18S-F2 (TTATTGTTTTGGTTTTTG) and PL-18S-R2 (AAACCAAAATTACAATAAAA) and probe PL-18S-P2 (GGAGATTATGGAGTTGTGTGATA), which amplify and detect DNA fragments of $82 \mathrm{bp}$ in length. The exogenous control was targeted by primers Lambda New F1 (AATATTGGTAGATTATGTTTGTG), Lambda New R1 (CTATCATCAAATCATACAATACC) and probe Lambda New P1 (TGATGTGATAGGAAGAATTTGTTGTTGTTGTTGTTG), which amplify a 100bp fragment of the Lambda bacteriophage DNA. The 18S rDNA and Lambda probes are intercalating, self-quenching probes, labeled with individual fluorophores (FAM and HEX, respectively) enabling the PCR to be performed as a duplex reaction. 


\subsection{PCR Preparation, Conditions, and Interpretation}

The PCR mixture was prepared by using $10 \mu \mathrm{L}$ of $2 x$ SensiFast (Bioline), $90 \mathrm{ng}$ of each primer PL-18S-F2/PL-18S-R2 and 8 pmol probe PL-18S-P2, 4ng primer Lambda New F1, 40ng primer Lambda New R1 and 3pmol probe Lambda New $\mathrm{P} 1,3.5 \mu \mathrm{L}$ of template, and molecular grade $\mathrm{H}_{2} \mathrm{O}$, to a final volume of $20 \mu 1$. All DNA templates were tested in 10 PCR replicates. A negative template control reaction was included in each PCR run. PCRs were run on the MIC PCR thermal cycler (Bio Molecular Systems, Upper Coomera, Australia) using the following parameters: $95^{\circ} \mathrm{C}$ for $3 \mathrm{~min}$, and 50 cycles of $95^{\circ} \mathrm{C}$ for $2 \mathrm{~s}$ and $50{ }^{\circ} \mathrm{C}$ for $10 \mathrm{~s}, 55^{\circ} \mathrm{C}$ for $10 \mathrm{~s}$ (data acquisition step) and $60^{\circ} \mathrm{C}$ for $10 \mathrm{~s}$.

The new assay was tested against the Schönian method by processing the equivalent concentration of Leishmania cells or genomic DNA, diluting these in molecular grade $\mathrm{H}_{2} \mathrm{O}$, and heating at $70^{\circ} \mathrm{C}$ for 15 minutes. Next, these lysates were processed on the GS-mini, using the MagPurix Viral/Pathogen Nucleic Acids Extraction Kit (Zinexts Life Science, Taipei, Taiwan) on the GS-mini, following the manufacturers' instructions. The eluates were diluted in the same fashion as the bisulphite-treated eluates and amplified in CPCR triplicates, according to the methodology developed by Schönian et al., with primers LITSR: CTGGATCATTTTCCGATG and L5.8S: TGATACCACTTATCGCACTT (targeting the ssu rRNA and 5.8S rRNA, respectively) [8].

\section{Results}

\subsection{Specificity of the Real-Time PCR Assay Using Quantitated Cultured Cell or Purified DNA Standards}

DNA converted from the panel of seven Leishmania quantitated standards (L. donovani, L. braziliensis, L. tropica, L. amazonensis, L. major, L. mexicana and L. infantum) were detected by the $18 \mathrm{~S}$ rDNA assay (Table 2). As displayed in Table 2, there was a concordance between these results and the Schönian method, as all Leishmania species tested were detected [8].

Table 2. Detection limit of the conventional and novel PCR assays.

\begin{tabular}{cccc}
\hline Species & Supplier & Schönian Method & Novel Method \\
\hline L. donovani & ATCC & 100 cells/PCR & 10 cells/PCR \\
\hline L. braziliensis & ATCC & 100 cells/PCR & 10 cells/PCR \\
\hline L. tropica & ATCC & 100 cells/PCR & 10 cells/PCR \\
\hline L. amazonensis & ATCC & 100 cells/PCR & 10 cells/PCR \\
\hline L. mexicana & ATCC & 100 cells/PCR & 100 cells/PCR \\
\hline L. major & ATCC & 10 cells/PCR & 10 cells/PCR \\
\hline L. infantum & Vircell & 1000 copies/PCR & 10 copies/PCR \\
\hline
\end{tabular}

\subsection{Specificity of the Real-Time PCR Assay Using Negative Control Samples}

DNA, extracted from 76 negative clinical samples, did not produce any PCR products using the new assay, giving a specificity of $100 \%$ [8].

\subsection{Specificity of the Real-Time PCR Assay Using Cross-Reactivity Specimens}

To further investigate the specificity of the assay, a panel of DNA from 43 other phylogenetically related organisms, or those with a differential diagnosis related to leishmaniasis, was tested (Table 1). No PCR products were detected from any of these specimens, giving a specificity of $100 \%$.

\subsection{Limit of Detection of the Real-Time PCR Assay Using Quantitated Standards}

The analytical sensitivity of the assay was evaluated using quantitated DNA and cell culture standards. Ten-fold serial dilutions were tested in the assay, and the LOD for Leishmania was shown to 
be 10 cellular/genomic copies per PCR reaction, although this LOD differed between species, as outlined in Table 2. For L. braziliensis, for example, the LOD was 10 cellular copies, and an average of 38.7 cycle threshold $\left(\mathrm{C}_{\mathrm{T}}\right)$ value was determined after testing the sample in $10 \mathrm{PCR}$ replicates. When L. braziliensis was tested by the Schönian method, the LOD was 100 cellular copies/PCR when tested in triplicate (Figure 1). ATCC quantitation was given in cells $/ \mu \mathrm{L}$ and Vircell quantitation was given in copies $/ \mu \mathrm{L}$, so this nomenclature has been upheld.

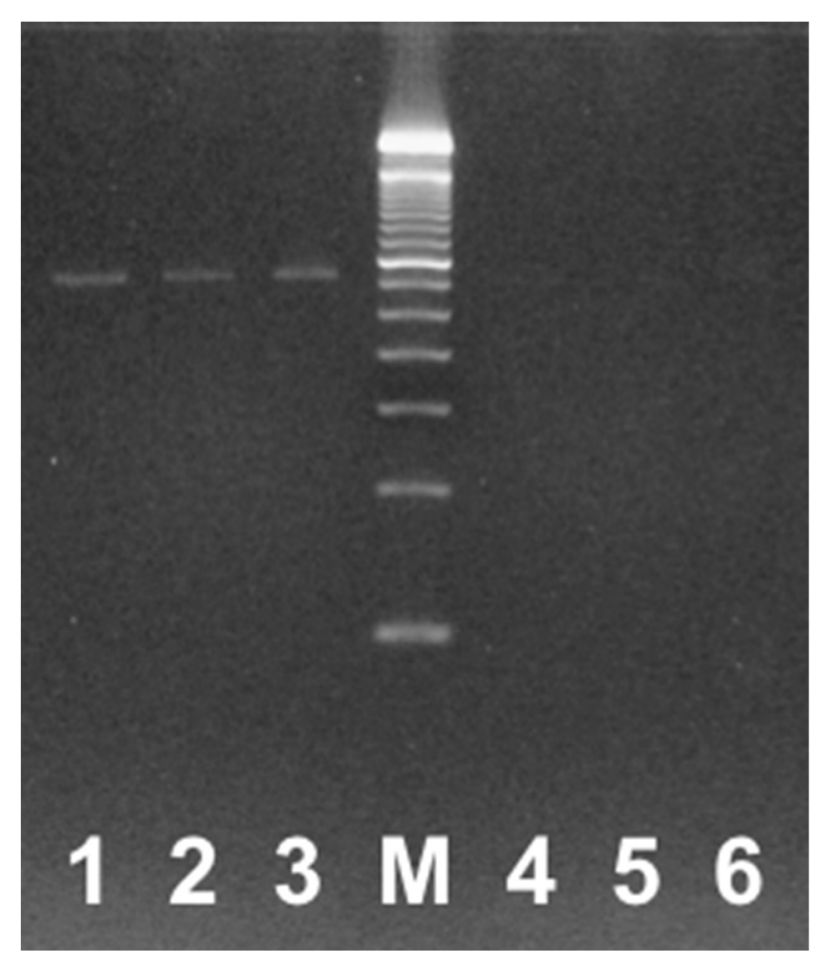

Figure 1. Sensitivity of the ITS1 CPCR assay for L. braziliensis, gel electrophoresis of conventional PCR result, using the Schönian method. Lanes 1, 2 and 3 are 100 copies/PCR; lane M is the 100bp ladder size standard, lanes 4, 5 and 6 are 10 copies/PCR.

\subsection{Sensitivity of the Real-Time PCR Assay Using Clinical Sample DNA}

Previously extracted DNA from 67 clinical tissue samples was available from patients with confirmed diagnosis of cutaneous leishmaniasis. Although clinical data were not available for all specimens, of those samples with data available, 32 (72.7\%) were male, and the age range was between one and 73 years. Forty-two patients had data available on previous travel; 21 (50.0\%) of these patients had been to the middle east, $11(26.2 \%)$ had been to South America, three $(7.1 \%)$ had been to southern Europe, one (2.4\%) to South Asia and five patients (11.9\%) had been to multiple geographic regions. Reason for travel data were available for 39 patients; 26 (66.7\%) were travellers, nine were immigrants (28.2\%) and two (5.1\%) were members of the army. Resulting cPCR (Schönian method) and restriction fragment length polymorphism analysis were used for detection and species differentiation, respectively [8]. Of the 67 clinical samples, the novel assay was detected in 65 , thus $97.0 \%$ concordance was achieved between the previous method and the $18 \mathrm{~S}$ assay.

\subsection{Precision of the Real-Time PCR Assay Using Quantitated Standards}

Standard curves were produced for L. braziliensis and L. tropica, testing 10-fold serial dilutions in PCR triplicates, giving an $\mathrm{R}^{2}$ value of 0.9945 for L. braziliensis (Figure 2a,b). This is a measure of the linearity of the generated curves and reflects efficiency and reproducibility. Error bars depict $95 \%$ confidence intervals, based upon two experimental replicates, comprising three PCR technical replicates 
each. To measure the intra-experiment precision and agreement between experiments, five experiments were each performed over five consecutive days, with three replicates at two cellular concentrations for each species (Table 3). The results considered over 236 replicates, with four negative replicates for L. tropica excluded. Low coefficients of variation (CVs), related to intra-experiment variability, were observed, all $<10 \%$. These findings provide additional support that this novel, real-time PCR provides efficient and precise quantification of DNA within and between experiments.

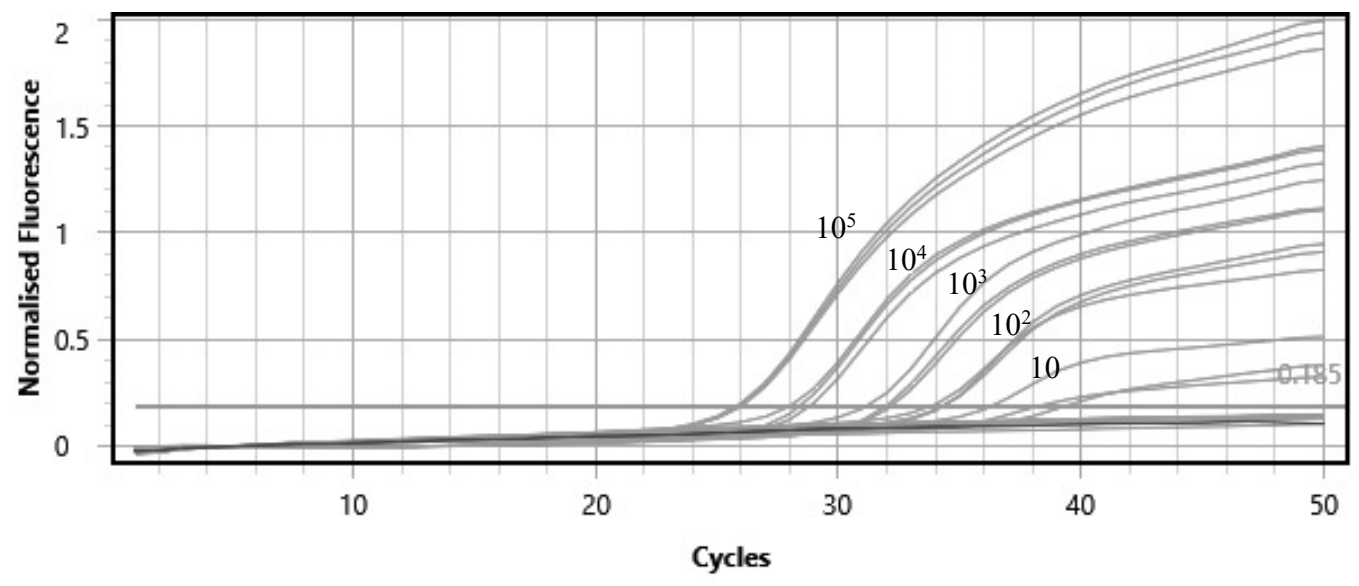

(a)

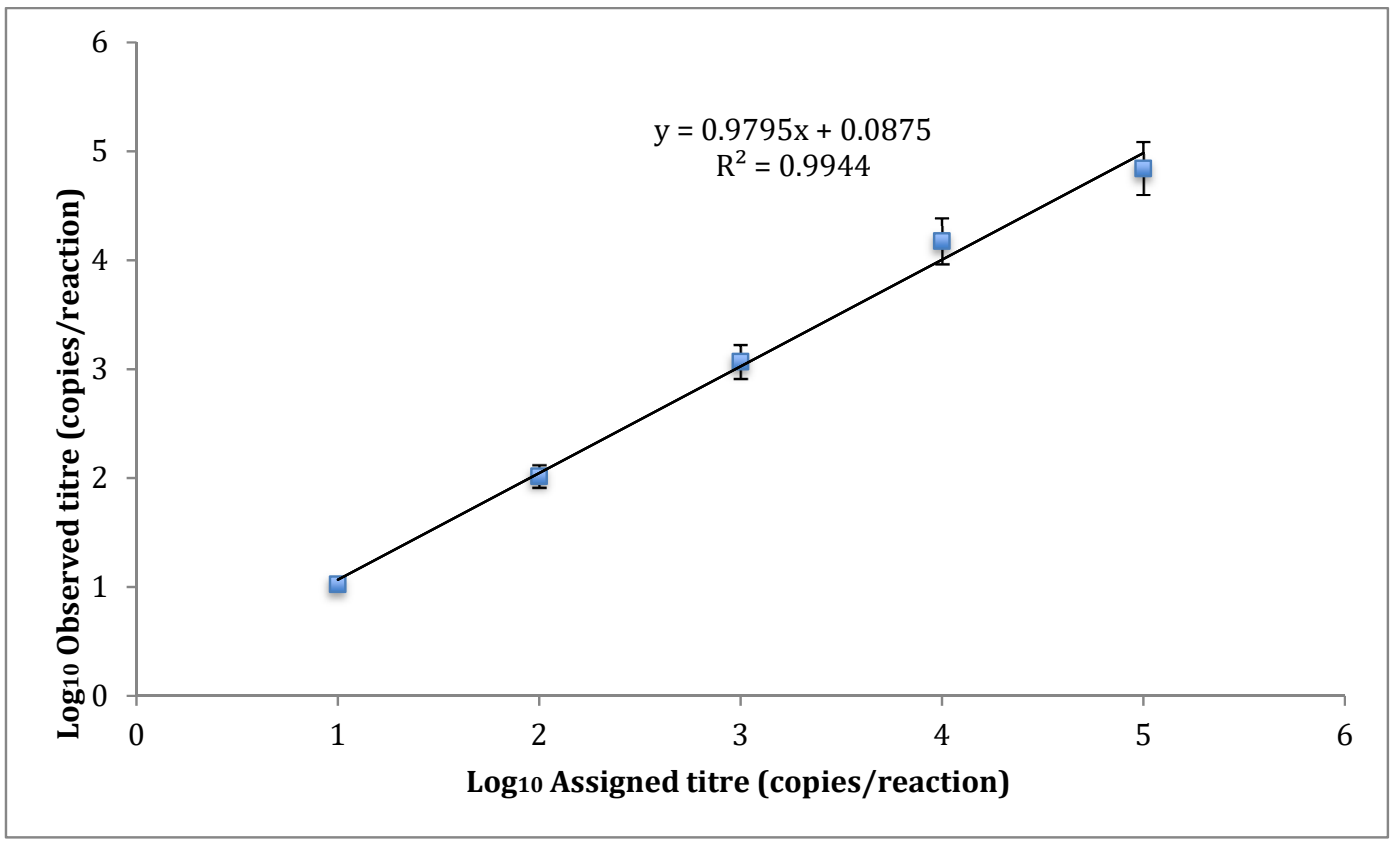

(b)

Figure 2. Sensitivity of the novel qPCR assay for L. braziliensis. (a) FAM channel amplification curves, using 10-fold serial dilutions from $10^{5}$ to 0.1 copies per PCR, tested in PCR triplicate. (b) Graphic depiction of the linear range of detection (10 to $10^{5}$ copies per reaction). Error bars represent $95 \% \mathrm{CI}$. 
Table 3. Summary of the Observed Precision Estimates for the novel assay.

\begin{tabular}{cccc}
\hline Leishmania Species and Copy Number & Mean $(\mathbf{C t})$ & SD $(\mathbf{C t})$ & CV (\%) \\
\hline L. donovani 1000 c/PCR & 30.26 & 0.88 & 2.92 \\
\hline L. donovani 100 c/PCR & 33.28 & 0.99 & 2.98 \\
\hline L. braziliensis 100 c/PCR & 30.78 & 0.87 & 2.84 \\
\hline L. braziliensis 10 c/PCR & 33.71 & 0.67 & 1.99 \\
\hline L. tropica 100 c/PCR & 34.07 & 0.95 & 2.80 \\
\hline L. tropica 10 c/PCR 1 & 37.83 & 2.31 & 6.11 \\
\hline L. amazonensis 100 c/PCR & 31.29 & 1.09 & 3.50 \\
\hline L. amazonensis 10 c/PCR & 34.24 & 2.19 & 6.39 \\
\hline L. mexicana 1000 c/PCR & 33.08 & 1.19 & 3.61 \\
\hline L. mexicana 100 c/PCR & 36.22 & 1.52 & 4.19 \\
\hline L. major 100 c/PCR & 31.96 & 0.84 & 2.62 \\
\hline L. major 10 c/PCR & 35.09 & 0.74 & 2.10 \\
\hline L. infantum 1000 c/PCR & 29.44 & 1.22 & 4.13 \\
\hline L. infantum 100 c/PCR & 32.23 & 1.47 & 4.57 \\
\hline
\end{tabular}

${ }^{1}$ For L. tropica, only $2 / 3$ replicates were achieved on four of the five consecutive days tested. In order to assess mean, $\mathrm{SD}$ and $\mathrm{CV}$, the negative data points were excluded from the data set.

\subsection{Internal Control Reaction}

No samples showed inhibition of the exogenous control.

\section{Discussion}

The development of a multiplexed, real-time PCR, targeting the $18 \mathrm{~S}$ rDNA to detect all Leishmania species and the associated automated bisulphite conversion system, is described. The assay was validated on DNA and cell standards and the limit of detection, using seven individual strains of Leishmania. The LOD was compared with the method of Schönian et al. [8] and, as can be seen from Table 2, the LOD of all seven species improved upon using the real-time PCR method [8]. No cross-reactivity was observed using a panel of 43 possible cross-reacting organisms (Table 1) and 76 negative tissue samples, making the assay exclusive to Leishmania DNA detection. For clinical performance, the DNA of 67 previously described positive tissue samples were tested, alongside a conventional PCR method, as described by Schönian et al., and 65 samples tested positive in the 18S rDNA real-time PCR assay [8]. The Schönian method is based on the ITS1 region, a gene also located on the ribosomal DNA array, and thus present in the same number of copies as the 18S rRNA gene [12]. The novel assay includes an exogenous control, which controls for extraction and PCR performance, and an external positive control, controlling for PCR performance. The inclusion of quality controls, both internal and external, was highlighted as important in Leishmania detection assays [13]. The turn-around time is less than 2.5 hours from sample to result, and the system has a small laboratory footprint (the area required in the laboratory for instrumentation) of $75 \mathrm{~cm}$ by $75 \mathrm{~cm}$.

The assay is based on the gene coding for the small subunit rRNA, a highly conserved region of the ribosomal DNA, located on chromosome 27. This gene was used for the detection of Leishmania in other assays, due to its excellent sensitivity, attributed to the fact that it is a multicopy gene, which is transcribed into abundant rRNA found in the cytoplasm, where it is predicted to be present at $10^{4}$ copies $[7,14-16]$.

The test utilises bisulphite conversion technology, whereby the genome is simplified to three nucleobases: A, T and G (Figure S1). This simplification of the genome enables easier design of primers and probes across subtypes and species variants, as single oligonucleotide sets can be designed to cover 
a diverse population and reduce the need for multiplexing, in order to capture all species. Furthermore, the increase in homology allows for different primer and probe sets of differing targets to be designed with similar melting temperatures (Tm), reducing potential issues with specificity (Table S1). This was previously demonstrated in two clinical trials, where nearly $100 \%$ sensitivity and specificity were achieved by the increased homology and similar Tm of the primers and probes designed for the assays $[17,18]$. Bisulphite conversion technology is already in use in various diagnostic laboratories in the detection of clinical sample types, including gastro-intestinal infections [18,19]. The bisulphite conversion is included in the initial lysis step and therefore requires no extra steps by the end user. This is the first Leishmania detection assay exploiting bisulphite technology. The bisulphite conversion technology can also be used in an assay designed to differentiate Leishmania species. As there are over 20 Leishmania species pathogenic to humans, these will need to be multiplexed with up to four other targets into at least five panels [20]. A similar Tm greatly reduces the risk of non-specific amplification, as a lower melting temperature can be used across the PCR cycling protocol, but will accommodate all targets. In this way, a future assay may be designed to incorporate the novel pan-Leishmania assay to screen a given sample, then a reflex assay may be used to identify the causative Leishmania species. In intercalating self-quenching probes, such as those used in this assay, the fluorescent dye and quencher are at separate ends, that are in a hairpin conformation when not bound to target [21]. This gives less non-specific fluorescence, as the probe is in close proximity to the quencher, and, thus, is more effectively quenched.(See Supplementary Materials)

Leishmania DNA-based detection in the laboratory is dominated by cPCR, nested PCR or qPCR. Conventional PCR has sensitivities ranging from 56\% to $100 \%$, depending on clinical specimen and gene target $[8,22]$. In nested PCR, an inner and outer set of primers are designed and tested in two rounds to increase sensitivity and specificity [23]. In an Iranian study of cutaneous leishmaniasis patients, it gave a sensitivity of $100 \%$ [24]. Both these methods, however, are time-consuming and laborious, requiring gel electrophoresis and a transilluminator for imaging post-PCR. This may also leave the laboratory open to contamination risk during these post-PCR methods. Quantitative PCR is a closed-tube system, where one step is required between DNA addition and result, and results may be read in real-time [25]. It achieves sensitivities and specificities of up to 100\% [26,27]. The novel qPCR achieved a lower LOD than CPCR, an outcome seen in other Leishmania assays utilising various targets $[14,28,29]$. Our future studies will determine the clinical sensitivity of samples previously tested positive for visceral leishmaniasis, to complement the clinical data obtained here.

Currently, there are very few commercial assays available on the market for the detection of all Leishmania species, particularly those based on the detection of Leishmania DNA, however, no formal evaluations are described in the scientific literature. Primer Design provide a primer and probe set with mastermix and controls, which claims to detect all Leishmania species, based on the cytochrome $b$ gene. This is a qPCR test, providing lyophilized components, with a sensitivity of 100 copies (http:/www.genesig.com/assets/files/leishmania_spp_std.pdf). Another assay detects L. major only (MyBioSource), through a qPCR assay containing the primers, probes, mastermix and controls. It claims a sensitivity of 100 copies of target template (https://www.mybiosource. com/images/tds/protocol_manuals/000000-799999/MBS486088_Easy.pdf). BioKits have a cPCR kit detection Leishmania spp., containing ready-to-use PCR mix and positive control, with a sensitivity of 20 copies/mL (http://www.biokits.com/productinfo/3587/Leishmania-sp.-PCR-Detection-Kit.html). The US army has an FDA-approved Leishmania qPCR detection kit called SMART Leish, developed in conjunction with Cepheid and the Walter Reed Army Institute of Research for the diagnosis of species associated with cutaneous leishmaniasis, with an LOD of four genome copies (http:/www.accessdata.fda.gov/cdrh_docs/pdf8/K081868.pdf). Its use is restricted to the Department of Defense laboratories, and thus not available commercially.

The novel pan-Leishmania assay provides a simple, economical solution for a high-tech molecular detection system, while retaining excellent sensitivity and specificity, that can be easily used in reference and satellite laboratories alike. Moreover, the automated nature of this system and its low cost means 
its application is feasible in many countries where leishmaniasis is endemic, which may lack the finances and expertise to implement high-tech laboratory diagnostics, such as qPCR. Such an efficient workflow and quality performance assures that reliable patient results can be diagnosed quickly, treatment regimes can be administered, and prognosis can be assessed.

Supplementary Materials: The following are available online at http://www.mdpi.com/2414-6366/4/4/135/s1, Figure S1: Conventional and bisulphite converted alignments for the $18 \mathrm{~S}$ rDNA gene, Table S1: Conventional and bisulphite converted primer and probe designs for the novel assay.

Author Contributions: Conceptualization, I.G., D.S., D.M. and J.E.; methodology, I.G.; validation, I.G.; formal analysis, I.G.; investigation, I.G.; resources, J.M.; data curation, I.G.; writing-original draft preparation, I.G.; writing-review and editing, D.S., D.M. and J.E; visualization, I.G.; supervision, D.S.; project administration, I.G.; funding acquisition, J.M.

Funding: This research received no external funding

Acknowledgments: We are grateful to Rogan Lee for the supply of Leishmania.

Conflicts of Interest: DM, IG and JM are employees of Genetic Signatures Ltd.

\section{References}

1. World Health Organisation. Control of the Leishmaniases; WHO Technical Report Series 949; World Health Organisation: Geneva, Switzerland, 2010.

2. Hotez, P.J. Human Parasitology and Parasitic Diseases: Heading Towards. Adv. Parasitol. 2018, 100, $29-38$. [PubMed]

3. Gualda, K.P.; Marcussi, L.M.; Neitzke-Abreu, H.C.; Aristides, S.M.A.; Lonardoni, M.V.C.; Cardoso, R.F.; Silveira, T.G.V. New Primers for Detection of Leishmania infantumusing Polymerase Chain Reaction. Rev. Inst. Med. Trop. Sao Paulo 2015, 57, 377-383. [CrossRef] [PubMed]

4. Ranasinghe, S.; Wickremasinghe, R.; Hulangamuwa, S.; Sirimanna, G.; Opathella, N.; Maingon, R.D.; Chandrasekharan, V. Polymerase chain reaction detection of Leishmania DNA in skin biopsy samples in Sri Lanka where the causative agent of cutaneous leishmaniasis is Leishmania donovani. Memórias Inst. Oswaldo. Cruz 2015, 110, 1017-1023. [CrossRef] [PubMed]

5. De Cassia-Pires, R.; de Melo, M.F.; Barbosa, R.D.; Roque, A.L. Multiplex PCR as a tool for the diagnosis of Leishmania skDNA and the gapdh housekeeping gene of mammal hosts. PLoS ONE 2017, 12, e0173922. [CrossRef]

6. Srivastava, P.; Mehrotra, S.; Tiwary, P.; Chakravarty, J.; Sundar, S. Diagnosis of Indian Visceral Leishmaniasis by Nucleic Acid Detection Using PCR. PLoS ONE 2011, 6, e19304. [CrossRef]

7. Tuon, F.F.; Neto, V.A.; Amato, V.S. Leishmania: origin, evolution and future since the Precambrian. FEMS Immunol. Med. Microbiol. 2008, 54, 158-166. [CrossRef]

8. Schönian, G.; Nasereddin, A.; Dinse, N.; Schweynoch, C.; Schallig, H.D.F.H.; Presber, W.; Jaffe, C.L. PCR diagnosis and characterization of Leishmania in local and imported clinical samples. Diagn. Microbiol. Infect. Dis. 2003, 47, 349-358. [CrossRef]

9. Roberts, T.; Barratt, J.; Sandaradura, I.; Lee, R.; Harkness, J.; Marriott, D.; Ellis, J.; Stark, D. Molecular Epidemiology of Imported Cases of Leishmaniasis in Australia from 2008 to 2014. PLoS ONE 2015, 10, e0119212. [CrossRef]

10. Lee, R.; Marriott, D.; Stark, D.; Van Hal, S.; Harkness, J. Leishmaniasis, an Emerging Imported Infection: Report of 20 Cases from Australia: Table. J. Travel Med. 2008, 15, 351-354.

11. Larrisey, M.P. EP17-A2 Evaluation of Detection Capability for Clinical Laboratory Measurement Procedures. Approved Guideline-Second Edition; Clinical and Laboratory Standards Institute: Wayne, PA, USA, 2012; pp. 2-18.

12. Töz, S.; Özensoy; Çulha, G.; Zeyrek, F.Y.; Ertabaklar, H.; Alkan, M.Z.; Vardarlı, A.T.; Gunduz, C.; Özbel, Y. A Real-Time ITS1-PCR Based Method in the Diagnosis and Species Identification of Leishmania Parasite from Human and Dog Clinical Samples in Turkey. PLoS Neglected Trop. Dis. 2013, 7, e2205.

13. Gonçalves-de-Albuquerque, S.D.C.; Pessoa-e-Silva, R.; Trajano-Silva, L.A.M.; de Morais, R.C.S.; Brandao-Filho, S.P.; de Paiva-Cavalcanti, M. Inclusion of quality controls on leishmaniases molecular tests to increase diagnostic accuracy in research and reference laboratories. Mol. Biotechnol. 2015, 57, 318-324. [CrossRef] [PubMed] 
14. León, C.M.; Muñoz, M.; Hernández, C.; Ayala, M.S.; Flórez, C.; Teherán, A.; Cubides, J.R.; Ramírez, J.D. Analytical Performance of Four Polymerase Chain Reaction (PCR) and Real Time PCR (qPCR) Assays for the Detection of Six Leishmania Species DNA in Colombia. Front. Microbiol. 2017, 8, 8. [CrossRef] [PubMed]

15. Vaish, M.; Mehrotra, S.; Chakravarty, J.; Sundar, S. Noninvasive Molecular Diagnosis of Human Visceral Leishmaniasis. J. Clin. Microbiol. 2011, 49, 2003-2005. [CrossRef] [PubMed]

16. Van Eys, G.J.J.M.; Schoone, G.J.; Kroon, N.C.; Ebeling, S.B. Sequence analysis of small subunit ribosomal RNA genes and its use for detection and identification of Leishmania parasites. Mol. Biochem. Parasitol. 1992, 51, 133-142.

17. Siah, S.P.; Merif, J.; Kaur, K.; Nair, J.; Huntington, P.G.; Karagiannis, T.; Stark, D.; Rawlinson, W.; Olma, T.; Thomas, L.; et al. Improved detection of gastrointestinal pathogens using generalised sample processing and amplification panels. Pathology 2014, 46, 53-59. [CrossRef]

18. Baleriola, C.; Millar, D.; Melki, J.; Coulston, N.; Altman, P.; Rismanto, N.; Rawlinson, W. Comparison of a novel HPV test with the Hybrid Capture II (hcII) and a reference PCR method shows high specificity and positive predictive value for 13 high-risk human papillomavirus infections. J. Clin. Virol. 2008, 42, 22-26. [CrossRef]

19. Stark, D.; Roberts, T.; Ellis, J.; Marriott, D.; Harkness, J. Evaluation of the EasyScreen ${ }^{\mathrm{TM}}$ Enteric Parasite Detection Kit for the detection of Blastocystis spp., Cryptosporidium spp., Dientamoeba fragilis, Entamoeba complex, and Giardia intestinalis from clinical stool samples. Diagn. Microbiol. Infect. Dis. 2014, 78, 149-152. [CrossRef]

20. Akhoundi, M.; Downing, T.; Votýpka, J.; Kuhls, K.; Lukeš, J.; Cannet, A.; Ravel, C.; Marty, P.; Delaunay, P.; Kasbari, M.; et al. Leishmania infections: Molecular targets and diagnosis. Mol. Asp. Med. 2017, 57, 1-29. [CrossRef]

21. Kjelland, V.; Stuen, S.; Skarpaas, T.; Slettan, A. Prevalence and genotypes of Borrelia burgdorferi sensu lato infection in Ixodes ricinus ticks in southern Norway. Scand. J. Infect. Dis. 2010, 42, 579-585. [CrossRef]

22. Saab, M.; El Hage, H.; Charafeddine, K.; Habib, R.H.; Khalifeh, I. Diagnosis of Cutaneous Leishmaniasis: Why Punch When You Can Scrape? Am. J. Trop. Med. Hyg. 2015, 92, 518-522. [CrossRef]

23. Haddad, M.H.F.; Ghasemi, E.; Maraghi, S.; Tavala, M. Identification of Leishmania Species Isolated from Human Cutaneous Leishmaniasis in Mehran, Western Iran Using Nested PCR. Iran. J. Parasitol. 2016, 11, 65-72.

24. Namazi, M.J.; Dehkordi, A.B.; Haghighi, F.; Mohammadzadeh, M.; Zarean, M.; Hasanabad, M.H. Molecular detection of Leishmania species in northeast of Iran. Comp. Haematol. Int. 2018, 27, 729-733. [CrossRef]

25. De Almeida, M.E.; Koru, O.; Steurer, F.; Herwaldt, B.L.; da Silva, A.J. Detection and Differentiation of Leishmania sin Clinical Specimens by Use of a SYBR Green-Based Real-Time PCR Assay. J Clin. Microbiol. 2017, 55, 281-290. [CrossRef] [PubMed]

26. Mohammadiha, A.; Mohebali, M.; Haghighi, A.; Mahdian, R.; Abadi, A.; Zarei, Z.; Yeganeh, F.; Kazemi, B.; Taghipour, N.; Akhoundi, B. Comparison of real-time PCR and conventional PCR with two DNA targets for detection of Leishmania (Leishmania) infantum infection in human and dog blood samples. Exp. Parasitol. 2013, 133, 89-94. [CrossRef] [PubMed]

27. Sudarshan, M.; Singh, T.; Chakravarty, J.; Sundar, S. A Correlative Study of Splenic Parasite Score and Peripheral Blood Parasite Load Estimation by Quantitative PCR in Visceral Leishmaniasis. J. Clin. Microbiol. 2015, 53, 3905-3907. [CrossRef] [PubMed]

28. Sterkers, Y.; Varlet-Marie, E.; Cassaing, S.; Brenier-Pinchart, M.-P.; Brun, S.; Dalle, F.; Delhaes, L.; Filisetti, D.; Pelloux, H.; Yera, H.; et al. Multicentric Comparative Analytical Performance Study for Molecular Detection of Low Amounts of Toxoplasma gondii from Simulated Specimens. J. Clin. Microbiol. 2010, 48, 3216-3222. [CrossRef]

29. Eroglu, F.; Koltas, I.S.; Uzun, S. Comparison of Clinical Samples and Methods in Chronic Cutaneous Leishmaniasis. Am. J. Trop. Med. Hyg. 2014, 91, 895-900. [CrossRef]

(C) 2019 by the authors. Licensee MDPI, Basel, Switzerland. This article is an open access article distributed under the terms and conditions of the Creative Commons Attribution (CC BY) license (http://creativecommons.org/licenses/by/4.0/). 